\title{
Evaluation of recent changes in genetic variability in Thoroughbred horses based on microsatellite markers parentage panel in Korea
}

\author{
Chul Song Park ${ }^{1, a}$, Sun Young Lee ${ }^{2, a}$, and Gil Jae Cho ${ }^{1, *}$
}

\author{
* Corresponding Author: Gil Jae Cho \\ Tel: +82-053-950-5978, \\ Fax: +82-053-950-5955, \\ E-mail: chogj@knu.ac.kr \\ ${ }^{1}$ College of Veterinary Medicine and Institute \\ of Equine Medicine, Kyungpook National \\ University, Daegu 41566, Korea \\ 2 Racing Laboratory, Korea Racing \\ Association, Gwacheon 13822, Korea \\ ${ }^{a}$ Contributed equally to this work. \\ ORCID \\ Chul Song Park \\ https://orcid.org/0000-0002-6495-3965 \\ Sun Young Lee \\ https://orcid.org/0000-0001-7377-0012 \\ Gil Jae Cho \\ https://orcid.org/0000-0001-6848-7335
}

Submitted Jun 11, 2021; Revised Jul 30, 2021; Accepted Aug 12, 2021
Objective: In this study, we aimed to investigate the recent changes such as allele frequencies and total probability of exclusion (PE) in Thoroughbred horses in Korea using short tandem repeat (STR) parentage panels between 2006 and 2016.

Methods: The genotype was provided for 5,988 horse samples with 15 microsatellite markers (AHT4, AHT5, ASB2, ASB17, ASB23, CA425, HMS1, HMS2, HMS3, HMS6, HMS7, HTG4, HTG10, LEX3 and VHL20).

Results: In our study, the observed number of alleles per locus ranged from 3 (HMS1) to 9 (ASB17) in 2006 and 4 (HMS1) to 9 (ASB2) in 2016, with a mean value of 6.28 and 6.40, respectively. Of the 15 markers, HMS2, HTG4, and CA425 loci had relatively low polymorphism information content $(<0.5000)$ in the Thoroughbred population. Mean levels of genetic variation in 2006 and 2016 were observed heterozygosity $\left(\mathrm{H}_{\mathrm{O}}\right)=0.708$, and expected heterozygosity $\left(\mathrm{H}_{\mathrm{E}}\right)=0.685$, as well as and $\mathrm{H}_{\mathrm{O}}=0.699$ and $\mathrm{H}_{\mathrm{E}}=0.682$, respectively. The $\mathrm{PE}$ was calculated for each group based on the allele frequencies of 14 or 15 STRs. The 2006 survey analyzed that PE was 0.9998 , but it increased to 0.9999 in 2016 after the HMS2 marker was added in 2011. The current STR panel is still a powerful tool for parentage verification that contributes to the maintenance of integrity in the Thoroughbred population.

Conclusion: The current STR panel is still a powerful tool for parentage verification that contributes to the maintenance of integrity in the Thoroughbred horses. However, continuous monitoring genetic variability is necessary.

Keywords: Individual Identification; Microsatellite Marker; Parentage Verification; South Korea; Thoroughbred Horse

\section{INTRODUCTION}

The first volume of Thoroughbred Stud Book was published in England in 1791 [1], and the first volume was published in Korea in 1998. Domestic foals can be listed in the Korean Stud Book (KSB) through appearance screening and paternity verification. In Korea, the paternity of Thoroughbred horses was tested via blood type until the late 1990s but was changed to microsatellite DNA analysis in 2002 [2].

Microsatellite polymorphism, i.e., short tandem repeat (STR) in a horse, was first reported by Ellegren et al [3] and Marklund et al [4]. Microsatellites have been used for genetic diversity assessment, genetic maps constructions, quantitative trait loci mapping and parentage testing $[5,6]$. The STR became a valuable tool for horse parentage verification and pedigree registration [7]. In 1998, at the Equine Genetic and Thoroughbred parentage Testing workshop hosted by the International Society for Animal Genetics (ISAG), an international panel with nine STRs for horse DNA typing was created, in 2011, three STRs were added, with 12 STRs currently recommended by ISAG. The International Stud Book 
Committee (ISBC) recommends using these 12 STRs for registration of Thoroughbred horses. It also requires that the total probability of exclusion (PE) value of parentage testing for Thoroughbred horses exceeds 0.9995 [8].

In Korea, Thoroughbred horse parentage testing started in 2002 using 14 STRs, including the nine (AHT4, AHT5, ASB2, HMS3, HMS6, HMS7, HTG4, HTG10, VHL20) STRs recommended by ISAG. In total, 15 STRs, including 12 (9 STRs plus ASB17, ASB23, HMS2) recommended by ISAG, have been routinely used since 2013 .

At present, in South Korea, 1,000 donkeys and $~ 27,000$ domestic horses exist, including 12,000 Thoroughbreds, 1,000 individuals from other horse breeds (e.g., Warmblood, Quarter horse), and 14,000 native horses (the Jeju Halla horse), of which $\sim 5,000$ Jeju horses which was designated as natural monument No. 347 by the government [9].

In Korea, $\geq 1,500$ Thoroughbred foals are born annually. In order for domestic-born Thoroughbred horses to be used as racehorses, they must be identified through appearance tests or genetic tests to be listed in the KSB. In addition, the horse's microsatellite DNA marker used in Korea was recognized for the registration of Thoroughbred horses from ISAG.

Stallions in Korea, have been replaced a lot so far; hence genetic diversity is also presumed to have changed. Therefore, in this study, we investigated the recent changes such as allele frequencies and PE in Thoroughbred horses in Korea using STR parentage panels between 2006 and 2016.

\section{MATERIALS AND METHODS}

\section{Ethical statement}

This study was a routine test for the registration of Thoroughbred horses in Korea and not approved by Research Ethical Committee, but sampling of this study was performed according to the guidelines of the Animal Ethics Committee of Korea Racing Authority in Korea for the care and use of experimental animals.

\section{Sample collection and DNA extraction}

A total of 5,988 Thoroughbred horses were examined. Genomic DNA was extracted from hair root samples using a MagExtractor System MFX-6100 (Toyobo, Osaka, Japan) according to the manufacturer's instructions [8].

\section{Microsatellite markers and analysis}

A total of 15 microsatellite loci (AHT4, AHT5, ASB2, ASB17, ASB23, CA425, HMS1, HMS2, HMS3, HMS6, HMS7, HTG4, HTG10, LEX3, and VHL20) were used for the analysis of Thoroughbred horses. Detailed characteristics of 15 STRs is as shown in Table 1. The fluorescent dye attached to the markers used in this study and the marker sizes (DNA base pair) shown in Figure 1. Polymerase chain reaction (PCR)
Table 1. Characteristics of the 15 microsatellite loci used in this study

\begin{tabular}{|c|c|}
\hline Loci & Primer sequence $\left(5^{\prime} \rightarrow 3^{\prime}\right)$ \\
\hline VHL20 & $\begin{array}{l}\text { CAAGTCCTCTTACTTGAAGACTAG, } \\
\text { AACTCAGGGAGAATCTTCCTCAG }\end{array}$ \\
\hline HTG4 & $\begin{array}{l}\text { CTATCTCAGTCTTGATTGCAGGAC, } \\
\text { СTCCСTCССTCССTCTGTTCTC }\end{array}$ \\
\hline AHT4 & $\begin{array}{l}\text { AACCGCCTGAGCAAGGAAGT, } \\
\text { GCTCCCAGAGAGTTTACCCT }\end{array}$ \\
\hline HMS7 & $\begin{array}{l}\text { CAGGAAACTCATGTTGATACCATC, } \\
\text { TGTTGTTGAAACATACCTTGACTGT }\end{array}$ \\
\hline AHT5 & $\begin{array}{l}\text { ACGGACACATCCCTGCCTGC, } \\
\text { GCAGGCTAAGGGGGCTCAGC }\end{array}$ \\
\hline HMS6 & $\begin{array}{l}\text { GAAGCTGCCAGTATTCAACCATTG, } \\
\text { CTCCATCTTGTGAAGTGTAACTCA }\end{array}$ \\
\hline ASB2 & $\begin{array}{l}\text { CCACTAAGTGTCGTTTCAGAAGG, } \\
\text { CACAACTGAGTTCTCTGATAGG }\end{array}$ \\
\hline HTG10 & $\begin{array}{l}\text { CAATTCCCGCCCCACCCCCGGCA, } \\
\text { TTTTTATTCTGATCTGTCACATTT }\end{array}$ \\
\hline HMS3 & $\begin{array}{l}\text { CCAACTCTTTGTCACATAACAAGA, } \\
\text { CCATCCTCACTTTTTCACTTTGTT }\end{array}$ \\
\hline HMS2 & $\begin{array}{l}\text { CTTGCAGTCGAATGTGTATTAAAT, } \\
\text { ACGGTGGCAACTGCCAAGGAAG }\end{array}$ \\
\hline ASB17 & $\begin{array}{l}\text { GAGGGCGGTACCTTTGTACC, } \\
\text { ACCAGTCAGGATCTCCACCG }\end{array}$ \\
\hline CA425 & $\begin{array}{l}\text { AGCTGCCTCGTTAATTCA, } \\
\text { CTCATGTCCGCTTGTCTC }\end{array}$ \\
\hline ASB23 & $\begin{array}{l}\text { GCAAGGATGAAGAGGGCAGC, } \\
\text { CTGGTGGGTTAGATGAGAAGTC }\end{array}$ \\
\hline HMS1 & $\begin{array}{l}\text { CATCACTCTTCATGTCTGCTTGG, } \\
\text { TTGACATAAATGCTTATCCTATGGC }\end{array}$ \\
\hline LEX3 & $\begin{array}{l}\text { ACACTCTAACCAGTGCTGAGACT, } \\
\text { GAAGGAAAAAAAGGAGGAAGAC }\end{array}$ \\
\hline
\end{tabular}

was performed according to the manufacturer's protocols (Applied Biosystems, Waltham, MA, USA). Of the 15 markers, HTG10 was examined by a single PCR.

The PCR was performed with a total volume of $15 \mu \mathrm{L}$ of the following mixture: $40 \mathrm{ng}$ of genomic DNA, $4.0 \mu \mathrm{L}$ of each primer, $1.25 \mathrm{mM}$ of dNTPs, $2.5 \mu \mathrm{L}$ of $10 \times$ reaction buffer, and $5 \mathrm{U}$ of Taq polymerase (Applied Biosystems, USA). For the single PCR, template DNA $2 \mu \mathrm{L}, 3$ pmol forward and reverse primers $2 \mu \mathrm{L}$ each, and sterile distilled water $6.5 \mu \mathrm{L}$ were mixed with PCR Premix buffer (Qiagen, Hilden, Germany), and adjusted to $25 \mu \mathrm{L}$.

Multiplex PCR amplification was as follows: initial denaturation for $10 \mathrm{~min}$ at $95^{\circ} \mathrm{C}$, followed by 30 cycles at $95^{\circ} \mathrm{C}$ for $30 \mathrm{~s}, 60^{\circ} \mathrm{C}$ for $30 \mathrm{~s}$ and $72^{\circ} \mathrm{C}$ for $1 \mathrm{~min}$. An extension step at $72^{\circ} \mathrm{C}$ for $60 \mathrm{~min}$ was added after the final cycle [10]. The single PCR was as follows: initial denaturation for $3 \mathrm{~min}$ at $95^{\circ} \mathrm{C}$, followed by 30 cycles at $95^{\circ} \mathrm{C}$ for $45 \mathrm{~s}, 56^{\circ} \mathrm{C}$ for $30 \mathrm{~s}$ and $72^{\circ} \mathrm{C}$ for $1 \mathrm{~min}$. An extension step at $72^{\circ} \mathrm{C}$ for $60 \mathrm{~min}$ was added after the final cycle.

The PCR was performed using a GeneAmp PCR System 9700 (Applied Biosystems, USA). The PCR products were 


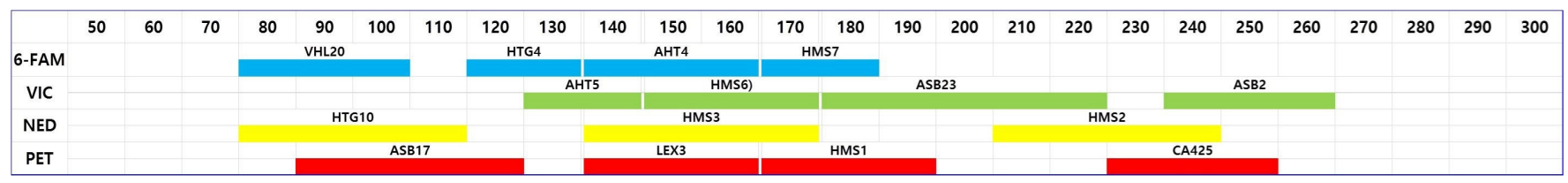

Figure 1. Allelic range of each marker including fluorescent dye used in this study.

electrophoresed and then analyzed using an ABI $3130 \mathrm{xl}$ Genetic Analyzer (Applied Biosystems, USA). The genotype of each of the 15 STRs was determined using Genotyper/ Genemapper software Ver.3.7 (Applied Biosystems, USA). Then, with the peak row data, the size of allelic genes (base pair) for each marker was determined based on the result of horse comparison test for STR conducted by ISAG.

\section{Statistical analysis}

Allelic frequencies, the number of alleles per locus were estimated by direct counting from observed genotype, and the observed heterozygosity $\left(\mathrm{H}_{\mathrm{O}}\right)$, expected heterozygosity $\left(\mathrm{H}_{\mathrm{E}}\right)$, polymorphism information content (PIC), and PE were computed using the Cervus ver. 3.0.3 [11].

\section{RESULTS}

\section{Allele frequencies and expected heterozygosities}

In our study, 15 microsatellites were used to identify the genetic diversity of Thoroughbred horses. Allele frequency at each locus is shown in Table 2. The observed number of alleles per locus ranged from 3 (HMS1) to 9 (ASB17) in 2006 and 4 (HMS1) to 9 (ASB2) in 2016, with a mean value of 6.28 and 6.40, respectively. Of the 15 markers, HMS2, HTG4, and CA425 loci had relatively low PIC $(<0.5000)$ in Thoroughbred horses. Mean levels of genetic variation in 2006 and 2016 were $\mathrm{H}_{\mathrm{O}}=0.708$ and $\mathrm{H}_{\mathrm{E}}=0.685$ as well as $\mathrm{H}_{\mathrm{O}}=0.699$ and $\mathrm{H}_{\mathrm{E}}=0.682$, respectively (Tables 3 and 4 ).

Table 2. Allelic frequencies calculated from 5,988 Thoroughbred horses

\begin{tabular}{|c|c|c|c|c|c|c|c|c|c|c|c|c|c|c|c|c|c|}
\hline \multirow{2}{*}{ Markers } & \multirow{2}{*}{ Years } & \multicolumn{16}{|c|}{ Alleles and frequencies DNA type } \\
\hline & & $\mathbf{B}^{1)}$ & $\mathbf{F}$ & $\mathbf{G}$ & $\mathbf{H}$ & $\mathbf{I}$ & $\mathbf{J}$ & $\mathbf{K}$ & $\mathbf{L}$ & M & $\mathbf{N}$ & 0 & $\mathbf{P}$ & $\mathbf{Q}$ & $\mathbf{R}$ & S & $\mathbf{U}$ \\
\hline \multirow[t]{2}{*}{ AHT4 } & 2006 & - & - & - & 0.2105 & - & 0.2241 & 0.1732 & 0.0004 & - & - & 0.3918 & - & - & - & - & - \\
\hline & 2016 & - & - & - & 0.1329 & - & 0.2354 & 0.2104 & - & - & 0.0004 & 0.4208 & 0.0001 & - & - & - & - \\
\hline \multirow[t]{2}{*}{ AHT5 } & 2006 & - & - & - & - & - & 0.1393 & 0.4911 & - & 0.2136 & 0.1233 & 0.0327 & - & - & - & - & - \\
\hline & 2016 & - & - & - & - & - & 0.2039 & 0.4678 & 0.0004 & 0.2112 & 0.0965 & 0.0201 & - & - & - & - & - \\
\hline \multirow[t]{2}{*}{ ASB2 } & 2006 & 0.0307 & - & - & - & - & - & 0.1304 & - & 0.1331 & 0.1366 & 0.1163 & 0.0117 & 0.2634 & 0.1778 & - & - \\
\hline & 2016 & 0.0245 & - & - & - & - & - & 0.0893 & 0.0001 & 0.2063 & 0.1501 & 0.0725 & 0.0068 & 0.264 & 0.1864 & - & - \\
\hline \multirow[t]{2}{*}{ HMS1 } & 2006 & - & - & - & - & 0.1739 & 0.4553 & & - & 0.3708 & - & - & - & - & - & - & - \\
\hline & 2016 & - & - & - & - & 0.1856 & 0.4124 & 0.0001 & - & 0.4019 & - & - & - & - & - & - & - \\
\hline \multirow[t]{2}{*}{ HMS2 } & 2006 & - & - & - & - & - & - & - & - & - & - & - & - & - & - & - & - \\
\hline & 2016 & - & - & - & 0.0198 & - & 0.0557 & 0.1375 & 0.7407 & 0.0464 & - & - & - & - & - & - & - \\
\hline \multirow[t]{2}{*}{ HMS3 } & 2006 & - & - & - & - & 0.5475 & - & 0.0004 & - & 0.1451 & 0.0393 & 0.1089 & 0.1467 & - & 0.0121 & - & - \\
\hline & 2016 & - & - & - & - & 0.5516 & - & - & - & 0.1274 & 0.0116 & 0.1383 & 0.1622 & - & 0.0089 & - & - \\
\hline \multirow[t]{2}{*}{ HMS6 } & 2006 & - & - & - & - & - & - & 0.1323 & 0.0276 & 0.2926 & - & 0.014 & 0.5319 & - & 0.0016 & - & - \\
\hline & 2016 & - & - & - & - & - & - & 0.1321 & 0.0353 & 0.3182 & - & 0.0023 & 0.5118 & 0.0003 & - & - & - \\
\hline \multirow[t]{2}{*}{ HMS7 } & 2006 & - & - & - & - & - & 0.0864 & 0.0012 & 0.1412 & 0.2385 & 0.2023 & 0.3304 & - & - & - & - & - \\
\hline & 2016 & - & - & - & - & - & 0.0854 & - & 0.1511 & 0.3065 & 0.2424 & 0.2145 & - & - & 0.0001 & - & - \\
\hline \multirow[t]{2}{*}{ HTG4 } & 2006 & - & - & - & - & - & - & 0.535 & 0.0012 & 0.4058 & 0.0249 & & 0.0331 & - & - & - & - \\
\hline & 2016 & - & - & - & - & - & - & 0.5659 & 0.0001 & 0.3764 & 0.0346 & 0.0001 & 0.0230 & - & - & - & - \\
\hline \multirow[t]{2}{*}{ HTG10 } & 2006 & - & - & - & - & 0.2782 & - & 0.1245 & 0.1669 & 0.1833 & & 0.0934 & - & 0.0008 & 0.1518 & 0.0012 & - \\
\hline & 2016 & - & - & - & - & 0.2826 & 0.0001 & 0.1173 & 0.2317 & 0.1863 & & 0.0879 & - & - & 0.0001 & 0.0007 & - \\
\hline \multirow[t]{2}{*}{ VHL20 } & 2006 & - & - & - & - & 0.2805 & - & - & 0.2307 & 0.3463 & 0.1374 & 0.0051 & - & - & - & - & - \\
\hline & 2016 & - & - & - & - & 0.2956 & - & 0.0001 & 0.2251 & 0.292 & 0.1854 & 0.0018 & - & - & - & - & - \\
\hline \multirow[t]{2}{*}{ ASB17 } & 2006 & - & - & 0.3261 & 0.0016 & - & - & - & - & 0.0315 & 0.2533 & 0.2171 & 0.0008 & 0.0008 & 0.1685 & 0.0004 & - \\
\hline & 2016 & - & - & 0.3756 & 0.0013 & - & - & - & - & 0.0351 & 0.1869 & 0.2314 & - & 0.0006 & 0.1690 & - & - \\
\hline \multirow[t]{2}{*}{ ASB23 } & 2006 & - & - & - & - & 0.0704 & 0.2817 & 0.2424 & 0.1782 & - & - & - & - & - & - & 0.2058 & 0.0214 \\
\hline & 2016 & - & - & - & - & 0.0949 & 0.3375 & 0.2075 & 0.1706 & - & - & - & - & - & - & 0.1626 & 0.0303 \\
\hline \multirow[t]{2}{*}{ LEX3 } & 2006 & - & 0.0039 & - & 0.2665 & - & 0.0004 & - & 0.0198 & 0.1362 & 0.1171 & 0.0529 & 0.4031 & - & - & - & - \\
\hline & 2016 & - & 0.0045 & - & 0.2787 & - & - & - & 0.0237 & 0.0936 & 0.086 & 0.0703 & 0.2352 & - & - & - & - \\
\hline \multirow[t]{2}{*}{ CA425 } & 2006 & - & - & - & - & 0.0323 & 0.1786 & 0.0019 & 0.0132 & 0.0268 & 0.6342 & 0.1128 & - & - & - & - & - \\
\hline & 2016 & - & - & - & - & 0.0139 & 0.1551 & 0.0129 & 0.0116 & 0.0134 & 0.6444 & 0.1485 & 0.0002 & - & - & - & - \\
\hline
\end{tabular}

\footnotetext{
${ }^{1)}$ Alphabetical allele code for all loci are identical to the assignment from International Society for Animal Genetics.
} 


\section{Exclusion probability}

The total PE was calculated for each group based on the allele frequencies of 14 or 15 STRs. The 2006 survey analyzed that PE was 0.9998, but it increased to 0.9999 in 2016 after the HMS2 marker was introduced in 2011.

\section{DISCUSSION}

Several microsatellite markers have been isolated from the horse genome [12], and the microsatellites showed multiple alleles and high heterozygosity among European horse breeds such as Thoroughbred horse. Several types of microsatellites are informative because of their high polymorphism, and they are useful in paternity testing of animals. In cattle, pig, horse, dog, and other populations, pedigree control has been performed on a routine basis in most countries [12-18]. These controls rely on microsatellite typing standardized through regular comparison tests with aid from the ISAG.

Blood typing tests of horses require fresh whole blood and include the costs of sampling by veterinarians, and transportation due to rapid transportation; the entire test process is manually conducted by humans. The results were also slightly inaccurate, with $97 \%$ to $99.5 \%$ in probability of parentage verification. However, since 2002, microsatellite DNA typing was introduced and used for the paternity as-

Table 3. Number of alleles, heterozygosity, PIC value and PE of 15 microsatellite markers in 5,988 Thoroughbred horses

\begin{tabular}{|c|c|c|c|c|c|c|}
\hline Markers & Years & No. of alleles & $\mathrm{H}_{0}$ & $\mathrm{H}_{\mathrm{E}}$ & PIC & PE \\
\hline \multirow[t]{2}{*}{ AHT4 } & 2006 & 5 & 0.781 & 0.722 & 0.674 & 0.474 \\
\hline & 2016 & 6 & 0.710 & 0.706 & 0.656 & 0.455 \\
\hline \multirow[t]{2}{*}{ AHT5 } & 2006 & 5 & 0.685 & 0.678 & 0.634 & 0.443 \\
\hline & 2016 & 6 & 0.689 & 0.685 & 0.683 & 0.442 \\
\hline \multirow[t]{2}{*}{ ASB2 } & 2006 & 8 & 0.852 & 0.831 & 0.809 & 0.663 \\
\hline & 2016 & 9 & 0.817 & 0.817 & 0.791 & 0.636 \\
\hline \multirow[t]{2}{*}{ HMS1 } & 2006 & 3 & 0.626 & 0.625 & 0.547 & 0.334 \\
\hline & 2016 & 4 & 0.616 & 0.634 & 0.556 & 0.341 \\
\hline \multirow[t]{2}{*}{ HMS2 } & 2006 & & & & & \\
\hline & 2016 & 5 & 0.420 & 0.427 & 0.400 & 0.243 \\
\hline \multirow[t]{2}{*}{ HMS3 } & 2006 & 7 & 0.645 & 0.644 & 0.608 & 0.424 \\
\hline & 2016 & 6 & 0.607 & 0.634 & 0.597 & 0.405 \\
\hline \multirow[t]{2}{*}{ HMS6 } & 2006 & 6 & 0.618 & 0.613 & 0.551 & 0.352 \\
\hline & 2016 & 6 & 0.629 & 0.618 & 0.551 & 0.349 \\
\hline \multirow[t]{2}{*}{ HMS7 } & 2006 & 6 & 0.767 & 0.766 & 0.728 & 0.545 \\
\hline & 2016 & 6 & 0.777 & 0.771 & 0.734 & 0.551 \\
\hline \multirow[t]{2}{*}{ HTG4 } & 2006 & 5 & 0.559 & 0.548 & 0.451 & 0.257 \\
\hline & 2016 & 6 & 0.537 & 0.536 & 0.444 & 0.252 \\
\hline \multirow[t]{2}{*}{ HTG10 } & 2006 & 8 & 0.804 & 0.814 & 0.788 & 0.630 \\
\hline & 2016 & 8 & 0.808 & 0.802 & 0.773 & 0.609 \\
\hline \multirow[t]{2}{*}{ VHL20 } & 2006 & 5 & 0.736 & 0.730 & 0.680 & 0.479 \\
\hline & 2016 & 6 & 0.737 & 0.742 & 0.695 & 0.495 \\
\hline \multirow[t]{2}{*}{ ASB17 } & 2006 & 9 & 0.762 & 0.753 & 0.710 & 0.520 \\
\hline & 2016 & 7 & 0.752 & 0.741 & 0.698 & 0.507 \\
\hline \multirow[t]{2}{*}{ ASB23 } & 2006 & 6 & 0.779 & 0.783 & 0.748 & 0.571 \\
\hline & 2016 & 6 & 0.784 & 0.779 & 0.747 & 0.573 \\
\hline \multirow[t]{2}{*}{ LEX3 } & 2006 & 8 & 0.756 & 0.731 & 0.691 & 0.505 \\
\hline & 2016 & 7 & 0.850 & 0.802 & 0.774 & 0.612 \\
\hline \multirow[t]{2}{*}{ CA425 } & 2006 & 7 & 0.553 & 0.551 & 0.513 & 0.332 \\
\hline & 2016 & 8 & 0.544 & 0.538 & 0.498 & 0.317 \\
\hline
\end{tabular}

$\mathrm{H}_{0}$ observed heterozygosity; $\mathrm{H}_{\mathrm{E}}$, expected heterozygosity; PIC, polymorphism information content; $\mathrm{PE}$, probability of exclusion.

Table 4. Allele diversity (the mean number alleles per locus), mean levels of genetic variation in 2006 and 2016 in Thoroughbred horses

\begin{tabular}{lcccccc}
\hline Years & Sample size & Allele diversity & $\mathbf{H}_{\mathbf{0}}$ & $\mathbf{H}_{\mathrm{E}}$ & PIC & PE \\
\hline 2006 & 1,285 & 6.28 & 0.708 & 0.699 & 0.652 & 0.9998 \\
2016 & 4,703 & 6.40 & 0.685 & 0.682 & 0.639 & 0.9999 \\
\hline
\end{tabular}

$\mathrm{H}_{0}$, observed heterozygosity; $\mathrm{H}_{\mathrm{E}}$, expected heterozygosity; PIC, polymorphism information content; $\mathrm{PE}$, total probability of exclusion. 
sessment of horses, most of these deficiencies in existing blood typing tests have been resolved. In Korea, a comparative analysis of the number of alleles, frequency of alleles, $\mathrm{Ho}, \mathrm{He}$, and PIC with microsatellite markers used in 2006 and 2016 showed that many stallions and mares had been replaced, but genetic diversity did not change significantly because of the small numbers of mares and stallions raised in the country. The total PE of the STR panel has changed significantly. This trend continues after adding HMS2 in 2011. Nevertheless, the total PE values for 14 or 15 STRs in Thoroughbred horses in Korea have been greater than the ISBC recommended values $(>0.9995)$ over the past decade.

In Korea, 15 STR markers are used to conduct parentage verification for approximately 1,500 Thoroughbred horses in a year. Parentage verification is determined using Mendel's genetic law. If a discrepancy occurs in one marker after the test judgment, it is assumed to be a mutation and additionally examined with three to five TKY marker; if two or more markers deviate from Mendel's genetic law, it is finally determined that they are not paternity. In general, approximately 10 to 12 heads $(0.7 \%$ to $0.8 \%)$ per year are not paternity.

On the basis of the PIC of each marker, the validity and reliability of the marker can be estimated. If the PIC value is $\geq 0.5000$, the reliability of the marker is valid for pedigree analysis. If it is $\geq 0.7000$, it has universal validity for analysis and can get a highly reliable result can be obtained.

It is currently under discussion and research to introduce single nucleotide polymorphism (SNP) instead of microsatellite DNA markers for parentage verification and individual identification of Thoroughbred horses. However, the results of this study are expected to be valid until the introduction of the SNP in the Thoroughbred population in Korea.

\section{CONFLICT OF INTEREST}

We certify that there is no conflict of interest with any financial organization regarding the material discussed in the manuscript.

\section{FUNDING}

This research was supported by the National Research Foundation of Korea, funded by the Ministry of Education, Science and Technology (NRF-2020R1I1A3067905).

\section{REFERENCES}

1. Gaffney B, Cunningham EP. Estimation of genetic trend in racing performance of thoroughbred horses. Nature 1988; 332:722-4. https://doi.org/10.1038/332722a0

2. Lee SY, Cho GJ. Parentage testing of Thoroughbred horse in Korea using microsatellite DNA typing. J Vet Sci 2006;7:63-
7. https://doi.org/10.4142/jvs.2006.7.1.63

3. Ellegren H, Jihansson M, Sandberg K, Andersson L. Cloning of highly polymorphic microsatellites in the horse. Anim Genet 1992;23:133-42. https://doi.org/10.1111/j.1365-2052. 1992.tb00032.x

4. Marklund S, Ellegren H, Eriksson S, et al. Parentage testing and linkage analysis in the horse using a set of highly polymorphic horse microsatellites. Anim Genet 1994;25:19-23. https://doi.org/10.1111/j.1365-2052.1994.tb00050.x

5. Li C, Wang Z, Liu B, et al. Evaluation of the genetic relationship among ten Chinese indigenous pig breeds with twenty-six microsatellite markers. Asian-Australas J Anim Sci 2004;17: 441-4. https://doi.org/10.5713/ajas.2004.441

6. Zhang JH, Xiong YZ, Deng CY. Correlations of genic heterozygosity and variances with heterosis in a pig population revealed by microsatellite DNA marker. Asian-Australas J Anim Sci 2005;18:620-5. https://doi.org/10.5713/ajas.2005. 620

7. Bowling AT, Eggleston-Stott ML, Byrns G, Clark RS, Dileanis S, Wictum E. Validation of microsatellite markers for routine horse parentage testing. Anim Genet 1997;28:247-52. https:// doi.org/10.1111/j.1365-2052.1997.00123.x

8. Tozaki T, Kakoi H, Mashima S, et al. Population study and validation of paternity testing for Thoroughbred horses by 15 microsatellite loci. J Vet Med Sci 2001;63:1191-7. https:// doi.org/10.1292/jvms.63.1191

9. Kim SM, Yun SW, Cho GJ. Assessment of genetic diversity using microsatellite markers to compare donkeys (Equus asinus) with horses (Equus caballus). Anim Biosci 2021;34: 1460-5. https://doi.org/10.5713/ab.20.0860

10. Dimsoski P. Development of a 17-plex microsatellite polymerase chain reaction kit for genotyping horses. Croat Med J 2003;44:322-35.

11. Kalinowski ST, Taper ML, Marshall TC. Revising how the computer program CERVUS accommodates genotyping error increases success in paternity assignment. Mol Ecol 2007;16:1099-106. https://doi.org/10.1111/j.1365-294x.2007. 03089.x

12. Tozaki T, Takezaki N, Hasegawa T, et al. Microsatellite variation in Japanese and Asian horses and their phylogenetic relationship using a European horse outgroup. J Hered 2003; 94:374-80. https://doi.org/10.1093/jhered/esg079

13. Kang BT, Kim KS, Min MS, et al. Microsatellite loci analysis for the genetic variability and the parentage test of five dog breeds in South Korea. Genes Genet Syst 2009;84:245-51. https://doi.org/10.1266/ggs.84.245

14. Cho GJ, Yang YJ, Kang HS, et al. Genetic diversity and validation of microsatellite markers for Jeju native horse parentage testing. Korean J Genet 2002;24:359-65.

15. Kim TH, Kim KS, Choi BH, et al. Genetic structure of pig breeds from Korea and China using microsatellite loci analysis. J Anim Sci 2005;83:2255-63. https://doi.org/10.2527/2005. 
$83102255 \mathrm{x}$

16. Cho GJ, Cho BW. Microsatellite DNA typing using 16 markers for parentage verification of the Korean native horse. AsianAustralas J Anim Sci 2004;17:750-4. https://doi.org/10.5713/ ajas. 2004.750

17. Sun W, Chang H, Ren HZ, et al. Genetic differentiation between sheep and goats based on microsatellite DNA.
Asian-Australas J Anim Sci 2004;17:583-7. https://doi.org/ 10.5713/ajas.2004.583

18. Yoon DH, Kong HS, Oh JD, et al. Establishment of an individual identification system based on microsatellite polymorphisms in Korean cattle (Hanwoo). Asian-Australas J Anim Sci 2005;18:762-6. https://doi.org/10.5713/ajas.2005. 762 